\title{
Neurotoxic effect of non-functionalized carbon nanospheres
}

\section{Efecto neurotóxico de las nanoesferas de carbono no funcionalizadas}

\author{
KASHINA, Svetlana†', FLORES-VILLAVICENCIO, Lerida Liss“", JACOBO-AZUARA, Araceli` and \\ GALINDO, Rosario*"'”
}

'Universidad de Guanajuato, Division of Natural and Exact Sciences, Department of Chemistry.

"Universidad de Guanajuato, Division of Natural and Exact Sciences, Department of Biology.

"' CONACYT Chair at the Universidad de Guanajuato, Division of Natural and Exact Sciences.

ID $1^{\text {st }}$ Author: Svetlana, Kashina / ORC ID: 0000-0003-4277-2060, CVU CONACYT ID: 516653

ID $1^{\text {st }}$ Coauthor: Lerida Liss, Flores-Villavicencio / ORC ID: 0000-0001-6349-6005, CVU CONACYT ID: 38686

ID $2^{\text {nd }}$ Coauthor: Araceli, Jacobo-Azuara / ORC ID: 0000-0003-0967-1858, CVU CONACYT ID: 104385

ID $3^{\text {rd }}$ Coauthor: Rosario, Galindo / ORC ID: 0000-0002-3612-1555, CVU CONACYT ID: 223987

\begin{abstract}
Objective. Different types of nanoparticles, including carbon ones, were tested for a variety of biological applications. Alongside with promising results, some undesired side effects were disclosed. Most biological studies were performed on highly functionalized carbon nanospheres, so the main objective of this study was to assess cytotoxicity of unfunctionalized carbon nanospheres synthetized by sol-gel method. We hypothesize that unfunctionalized material will present different cytotoxic pattern on cell culture. Methodology. 3 carbon nanosphere materials were synthetized by sol-gel method. Particles shape, size and functionalization were assessed. Cytotoxic effect of synthesized materials was evaluated on SH-SY5Y cell line using XTT and crystal violet assays and imaging. Contribution. In this work we have demonstrated that cytotoxic effect of carbon nanospheres can be attenuated by varying the conditions of synthesis.
\end{abstract}

\section{Resumen}

Objetivo. Diferentes tipos de nanopartículas, incluidas las de carbono, han sido analizadas para una gran variedad de aplicaciones biológicas. Si bien, los resultados han sido mayoritariamente prometedores, se revelaron algunos efectos secundarios no deseados. La mayoría de los estudios biológicos se realizaron en nanoesferas de carbono altamente funcionalizadas, por lo que el objetivo principal de este estudio fue evaluar la citotoxicidad de las nanoesferas de carbono sin funcionalizar y sintetizadas por el método sol-gel. Inferimos que el material no funcionalizado presentará un patrón citotóxico en el cultivo celular. Metodología. Se sintetizaron 3 materiales de nanoesferas de carbono por el método sol-gel. Se evaluó la diferencia en propiedades como forma y tamaño. El efecto citotóxico de los materiales sintetizados se evaluó en la línea celular SH-SY5Y utilizando ensayos XTT y cristal violeta y por el análisis estructural de organelos. Contribución. Se demostró que el efecto citotóxico de las nanoesferas de carbono puede atenuarse variando las condiciones de síntesis.

Nanoesferas de carbono, Neurotoxicidad, Sol-gel

Citation: KASHINA, Svetlana, FLORES-VILLAVICENCIO, Lerida Liss, JACOBO-AZUARA, Araceli and GALINDO, Rosario. Neurotoxic effect of non-functionalized carbon nanospheres. Journal of Scientific and Technical Applications. 2020. 6-17:10-13.

\footnotetext{
* Correspondence to Author (Email: mr.galindo@ugto.mx)

$\dagger$ Researcher contributing as first author.
} 


\section{Introduction}

Different nanomaterials are wildly investigated nowadays to be used for different biological applications, such as drug delivery, imaging, anticancer therapy, etc. Alongside with benefits, some materials present severe side effects: cells integrity disruption, metabolism modification, nuclei alterations among others.

Carbon nanoparticles (fullerenes, nanotubes and graphene) were promising materials for biological applications due to their biocompatibility, high surface area and chemical stability. However, in some cases they also present undesirable effects in biological studies. Carbon nanospheres are relatively new carbon nanometric-scaled material. Due to their high surface area and easiness to be functionalized and/or loaded with therapy agent, carbon nanospheres were extensively investigated. For instance, different carbon nanosphere materials were tested as imaging agents, drug delivery carriers, for phototherapy of cancer giving promising results. Nevertheless, some cytotoxic effects were disclosed for that materials too. It worth mention that almost in all studied cases, carbon nanoparticles were produced by hydrothermal synthesis, thus particles were functionalized with different hydrophilic groups. For that reason, our research group decided to assess cytotoxicity of unfunctionalized carbon nanospheres synthetized by sol-gel method. We hypothesize that unfunctionalized material will present different cytotoxic pattern on cell culture.

\section{Methodology}

Synthesis. For carbon nanospheres synthesis two-step method proposed by Liu et al was used. At the first step polymeric spheres were synthesized from resorcinol and formaldehyde under different temperatures and synthesis time. At the following step, polymeric materials were carbonized at $900{ }^{\circ} \mathrm{C}$ under nitrogen atmosphere for $3 \mathrm{~h}$.

Resulted carbon materials were named SG-1, SG-2 and SG-3.

Characterization. All materials were characterized by scanning electron microscopy. RAMAN and FTIR spectra also were obtained for the materials.
Biological experiments. Neuroblastoma SH-SY5Y cell line was used to evaluate neurotoxic effect of carbon nanospheres. Cells were grown in Dulbecco modified Eagles minimal essential medium supplemented with $10 \%$ of fetal bovine serum until they reached confluency. SH-SY5Y were plated at $10^{5}$ concentration into 96-well plate for $24 \mathrm{~h}$. After that, cells were incubated with different concentrations of nanospheres separately for 24 h. XTT assay was performed using standard protocol. Crystal violet (CV) assay was performed on the same cell culture immediately after XTT assay. The results were normalized to control. For cytoskeleton and nucleus staining, cells were plated on microscopy crystals for 24 $\mathrm{h}$ prior the staining. The staining was performed with Phalloidin-FITC and DAPI.

\section{Results}

Synthesis and characterization.

Scanning microscopy images have shown that particles of three studied materials possess spherical shape with diameters $600-700$ $\mathrm{nm}$, approximately.

FTIR have not evidenced any functional group peaks, which is consistent with temperature of carbonization.

RAMAN spectra have demonstrated only D and G bands, giving crystallinity ratio of materials of $60-70 \%$.

\section{Biological studies.}

Since XTT assay evaluate mitochondrial activity of cells and CV depicts total biomass, both tests should be performed in order to assess effect of nanoparticles on cell culture. 4 different concentrations of carbon nanospheres were implemented: 50, 100, 150 and $200 \mu \mathrm{g} / \mathrm{mL}$.

XTT and CV assay results are shown at Graphic 1 and Graphic 2, respectively. 


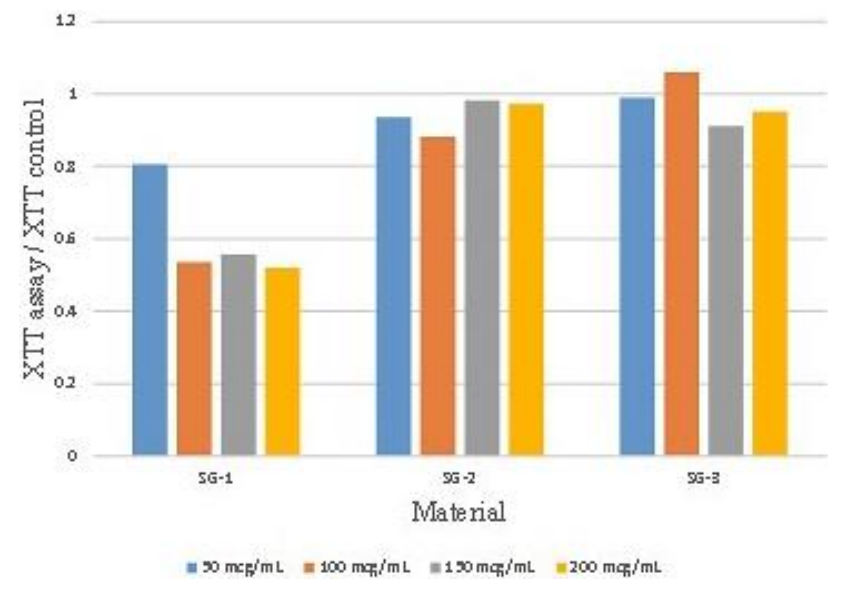

Graphic 1 Mitochondrial metabolic activity of SH-SY5Y exposed to carbon nanospheres

Source: kown work [Excel]

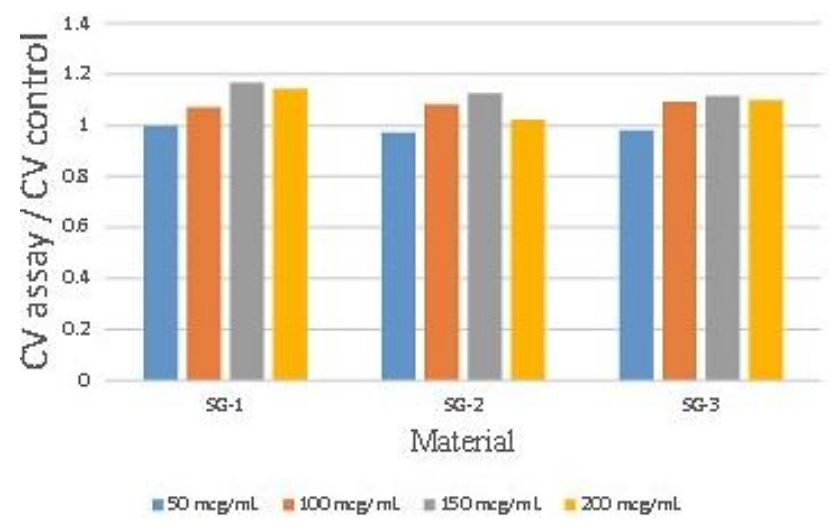

Graphic 2 Biomass of SH-SY5Y exposed to carbon nanospheres

Source: own work [Excel]

The results showed that the material SG1 present greater dose dependent cytotoxic effect on neuronal cells, giving almost $50 \%$ cell activity reduction. Cytotoxic effect of SG-2 and SG-3 is more moderate, with approximately $10 \%$ of mitochondrial activity reduction. We suppose that these differences may be caused by different surface geometry, such as pore size and its distribution, that resulted from distinct synthesis conditions. It is known that larger porosity leads to higher surface area, which may cause better interaction between particle and cell membrane.

This effect cannot be attributed to different cell mass, since CV assay did not show it decline, but rather it increases in some extend. For better understanding of particle-cell interactions, staining of cells after their exposure to the materials was performed (Figure 1).

The images showed that SG-1 is more damaging for both cytoskeleton and nucleus, meanwhile, SG-3 did not present significant differences comparing to control.

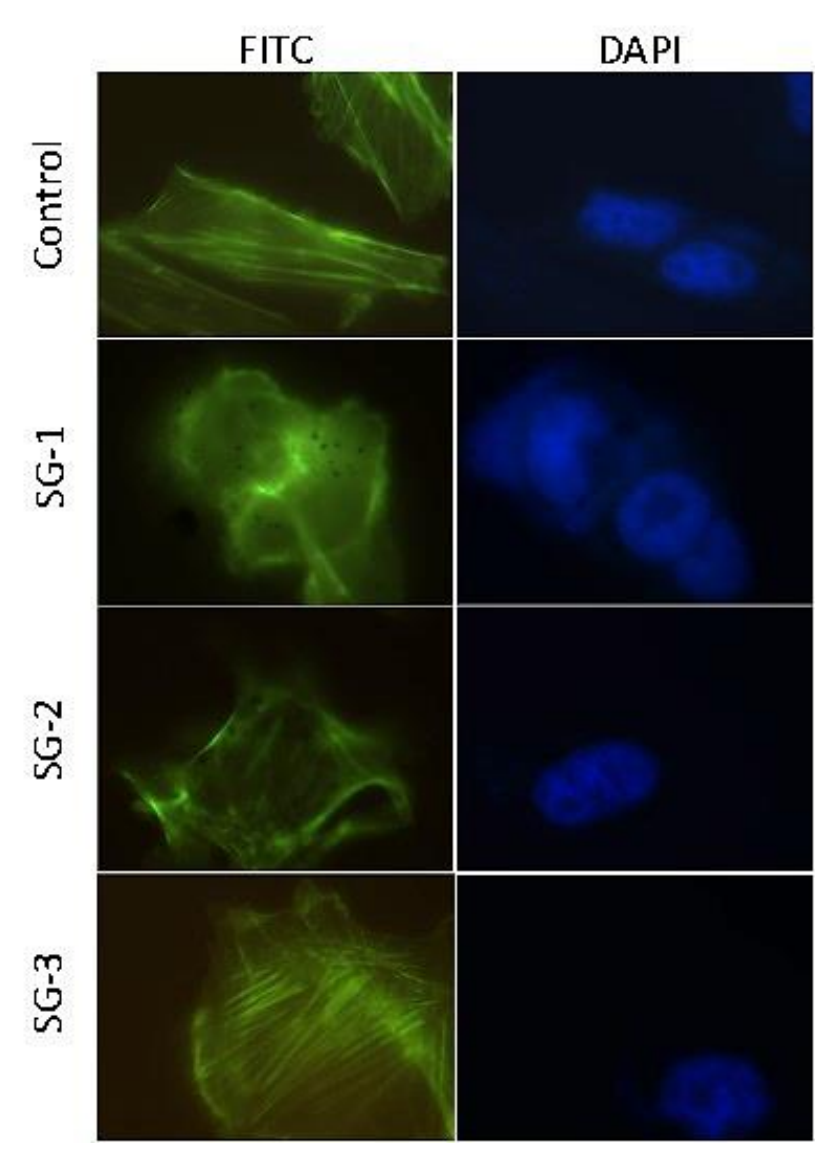

Figure 1 Cytoskeleton (FITC) and nucleus (DAPI) images Source: own work [PowerPoint]

\section{Conclusions}

Neurotoxic effect of unfunctionalized carbon nanosphere materials such as loss of cytoskeleton integrity and nuclei damage can be attenuated by different conditions of synthesis.

\section{References}

Liu, X., Yang, Z., Sun, J., Ma, T., Hua, F., \& Shen, Z. (2019). A brief review of cytotoxicity of nanoparticles on mesenchymal stem cells in regenerative medicine. International Journal of Nanomedicine, 14, 3875.

Du, X., Zhao, C., Zhou, M., Ma, T., Huang, H., Jaroniec, M., ... \& Qiao, S. Z. (2017). Hollow carbon nanospheres with tunable hierarchical pores for drug, gene, and photothermal synergistic treatment. Small, 13(6), 1602592.

Liu, J., Qiao, S. Z., Liu, H., Chen, J., Orpe, A., Zhao, D., \& Lu, G. Q. (2011). Extension of the Stöber method to the preparation of monodisperse resorcinol-formaldehyde resin polymer and carbon spheres. Angewandte Chemie International Edition, 50(26), 59475951. 
INIESTA PIÑA, L. E. (2020). Obtención de nanopartículas fotoluminiscentes de carbono a partir de la fragmentación de negro de carbono utilizando pulsos láser.

LAGUNA, E. P. (2020). Materiales híbridos a base de grafeno, polianilina y nanopartículas de oro para bioceldas de combustible. 